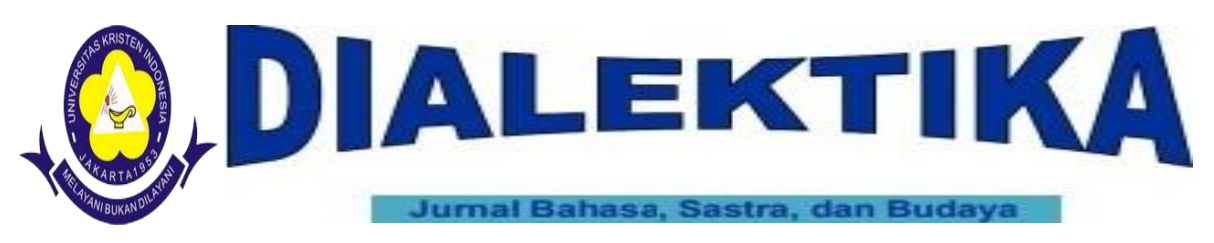

ISSN: 2338-2635

\title{
AN ERROR ANALYSIS ON THE TIYAO WRITTEN BY THE STUDENTS OF THE MANDARIN 3-YEAR DIPLOMA STUDY PROGRAM OF UNIVERSITAS JENDERAL SOEDIRMAN
}

\author{
Chendy A.P. Sulistyo ${ }^{1}$, Nunung Supriadi ${ }^{2}$ \\ 1,2 Mandarin Diploma Study program, Faculty of Humanity, University Jenderal Soedirman, Jl. Dr. \\ Soeparno No. 60 Karangwangkal Purwokerto Utara, 53122 \\ Correspondence Email: chendy.sulistyo@unsoed.ac.id
}

\begin{abstract}
Abstrak
Tiyao merupakan abstrak dari laporan tugas akhir yang ditulis oleh mahasiswa Program Studi D3 Bahasa Mandarin Universitas Jenderal Sudirman Purwokerto. Penelitian deskriptif-kualitatif ini berfokus pada kesalahan-kesalahan yang dilakukan mahasiswa dalam menulis laporan tugas akhir mereka. Peneliti mengamati dan menganalisis kesalahan yang ditemukan dalam kalimat dan faktor penyebab kesalahan tersebut. Selain itu, angket digunakan untuk mengungkapkan kesulitan yang dihadapi siswa dalam menulis tiyao mereka. Penelitian ini juga untuk meningkatkan kemampuan siswa dalam menulis tiyao dengan menggunakan bahasa baku tulisan Mandarin. Dalam pengumpulan data, peneliti melakukan observasi dan wawancara baik dengan mahasiswa maupun dosen Program Studi D3 Bahasa Mandarin Universitas Jenderal Sudirman untuk mengungkap secara faktual kondisi pembelajaran bahasa Mandarin. Hasil penelitian menunjukkan bahwa kesalahan mahasiswa Prodi D3 Mandarin dalam tiyaonya diklasifikasikan ke dalam tataran sintaksis, semantik, morfologi, dan wacana. Berdasarkan hasil penelitian disimpulkan bahwa kesalahan yang paling banyak dilakukan siswa dalam menulis tiyao mereka adalah pada tataran sintaksis, terutama dalam membentuk kalimat efektif.
\end{abstract}

Kata kunci: kesalahan, menulis, tiyao, Mandarin

\begin{abstract}
Tiyao is the abstract of a final project report written by the students of Mandarin 3-Year Diploma Study Program of Universitas Jenderal Soedirman, Purwokerto. This descriptive-qualitative research focused on the errors made by the students in writing the tiyao of their final project report. The researcher observed and analyzed the errors found in the sentences and the factors causing those errors. In addition, questionnaires were used to reveal the difficulties faced by the students in writing their tiyao. This research also aimed at improving the students' skills in writing tiyao using the Mandarin written standard language. In collecting the data, the researcher employed observation and interviews with both students and lecturers of the Mandarin 3-Year Diploma Study Program of Universitas Jenderal Soedirman to factually reveal the Mandarin learning conditions. The results showed that the Mandarin 3-Year Diploma Study Program students' errors in their tiyao were classified into syntactical, semantic, morphological, and discourse levels. Based on the research results, it was concluded that the most errors made by the students in writing their tiyao were at the syntactical level, especially in forming effective sentences.
\end{abstract}

Keywords: error, writing, tiyao, Mandarin 


\section{Introduction}

Phenomena on the increasing tourists, especially from China to Indonesia and investments made by China, make Mandarin language increase in Indonesia. This great opportunity encourages Indonesia to produce more skilled human resources, especially with a good Mandarin language mastery. Thus, Mandarin language education is greatly required to produce competent graduates with good Mandarin mastery. Universitas Jenderal Soedirman has a Mandarin 3-Year Diploma Study Program focusing on tourism and translation. 4 main competencies consisting of speaking, listening, reading, and writing are required in learning Mandarin. The students are also required to deepen their skills in translation and tourism to become competent graduates in both translation and tourism fields. To graduate from this 3-Year Diploma Study Program, each student must write a working practice report as their final project, consisting of abstract, introduction, literature review, general review, discussion, and conclusion. The report is written in the Indonesian language, but the abstract should be written in Mandarin, known as tiyao.

Tiyao is the report summary consisting of introduction, objectives, benefits, methods, results, and conclusions. The summary generally consists of 200 to 300 words. Thus, Tiyao makes the readers understand the report's purposes. However, many errors were still found in the tiyao written by the students. Thus, the researcher tried to research the tiyao written by the students due to its importance. It is expected that the results of this research can better improve the students' ability in writing their tiyao.

Based on the descriptions above, the research problems were formulated as follows: 1) What forms of errors found in the tiyao written by the students of Mandarin 3-Year Diploma Study Program of Universitas Jenderal Soedirman, 2) What factors causing the errors made by the students of Mandarin 3-Year Diploma Study Program of Universitas Jenderal Soedirman in writing their tiyao, 3) How to better improve the tiyao written by the students of Mandarin 3-Year Diploma Study Program of Universitas Jenderal Soedirman.

\section{Literature Reviews}

\section{Errors}

In learning a language (B2) after mastering the first language (B1), making errors is common. However, the level of one's errors will be different from the others. According to Chomsky (1965), errors are divided into two types (1) Error caused by a lack of knowledge knowing the rules of language developed in the second language system, and (2) Mistake caused by fatigue, tiredness, and lack of attention (known as performance factors). "Mistake" can be corrected if the speaker is reminded, while "Error" is a language distortion made by those learning 
a language at a certain level (Tarigan, 1988: 143). Burt and Kiparsky in Syafi'ie (1984) referred the use of "goof" as an error since used as 'goofing" in a verbal sentence or utterance and the use of "goof" as a mistake, since used as "goficon" in a sentence or utterance due to its grammatical errors.

According to Tarigan (1988: 145), errors are classified into four taxonomies: (1) Linguistic Category including phonology (speech), syntax and morphology (grammar), semantics and lexicon (meaning and vocabulary), and discourse (style); (2) Surface Scheme including omission, addition, malformation, and disordering; (3) Comparative, including development errors (interlingual errors), and others; (4) Communicative Effect, including global and local errors.

\section{Tiyao}

Tiyao is a report summary consisting of introduction, objectives, benefits, methods, results, and conclusions. Tiyao makes the readers understand the report's purposes. (Li 2016: 1) stated that the summary is generally written in 200 to 300 words.

Tiyao should be written in Mandarin standard language, yet the entire report can be written in standard Indonesian. Moeliono et al.(1988) stated that a standard language has three basic characteristics. First, dynamic stability in the form of fixed rules, yet flexible, allows systematic and orderly changes in vocabulary and terminology, developing various types needed in modern life. Some changes resulted from the implementation of rules had no strong reasons to justify deviations. Second, scholarship manifested in sentences, paragraphs, and other larger language units expressing orderly, logical, and reasonable thoughts. Language investigation is greatly important because modern science and technology sourced from foreign languages should be made in the standard Indonesian language. Third, uniformity standard. To some extent, the standardization process means a uniformity process of rules, not synchronization or uniformity of language variations.

Standardization of a language in writing a report involves several things. First, standard means fixed and not easy to change. Thus, definite language rules are required for the benchmarks of standard language for writing a report.

Mandarin standard language has several characteristics in both spoken and written purposes. First, the Mandarin standard language is used in official situations and not combined with a particular dialect or accent. Second, Mandarin standard language uses the provisions applicable in the Chinese spelling guidelines referring to 现代 汉语 词典 proposed by Lü（2016） 
. Third, Mandarin standard language covers the grammatical functions explicitly and completely consisting of subjects, predicates, and objects.

\section{Research Method}

This research used a descriptive-qualitative approach by conducting direct observations of the reports written by the students. The researcher also provided the question sheets distributed to the students in questionnaires to reveal the causes of errors made by the students in writing their tiyao by classifying, analyzing, discussing, and drawing conclusions.

The research data were the tiyao of reports (known as final projects) written by the Mandarin 3Year Diploma Study Program students graduating in 2018. The errors made by the students in writing their tiyao were then analyzed to conclude.

\section{Results and Discussion}

This section discussed the research results based on the classifications of errors made and described the causes. Thus, appropriate ways to reduce errors found in the tiyao written by the students might be recommended.

\section{Types of Errors}

Based on the theory of taxonomic errors in the Linguistic Category proposed by Tarigan (1988: 145), the errors made by the students in writing their tiyao were classified into four types: phonological, syntactical and morphological (grammatical), semantic and lexical (meaning and vocabulary), and discourse errors.

After analyzing the errors made in the tiyao written by the students, the researcher did not find any at the phonological or pronunciation level since those were in the form of written language. Instead, the errors were first found at the morphological level, such as in phrases and clauses; at the syntactical level, in using conjunctions and less effective sentences; at the semantic level, in word selection (diction); and at the discourse level, in incomplete sentences throughout the paragraphs.

Based on the analysis results, the following diagram illustrated the errors made by students. 

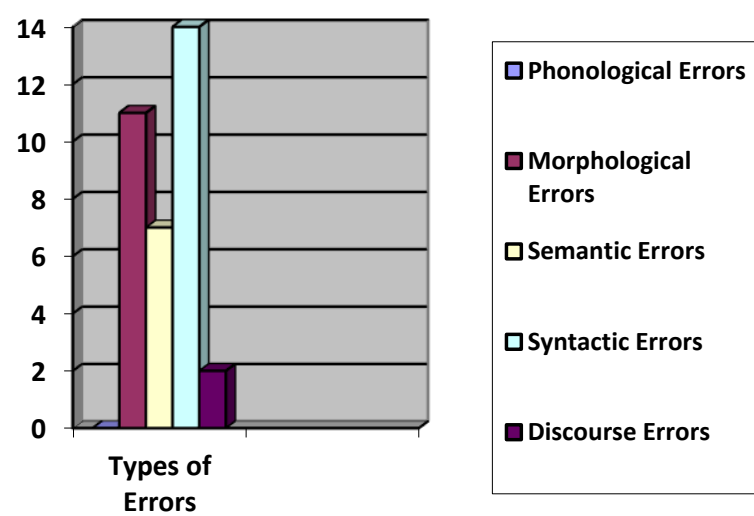

Based on the diagram, it was concluded that the most common errors found by the researcher are the syntactical ones, especially the omission of subjects in sentences and resulted in ineffective sentences due to the absence of subjects, as presented in the table below.

Table 1: Syntactic Errors

\begin{tabular}{|c|c|c|}
\hline No & Errors & Mandarin Standard Grammar \\
\hline 1. & $\begin{array}{l}\text { 翻译转单的赾程有 } \\
\text { 三个阶段。(*) } \\
\text { Proses } \\
\text { menerjemahan } \\
\text { brosur memiliki tiga } \\
\text { tahapan. }\end{array}$ & $\begin{array}{l}\text { 作者在翻译转单的赾程中有三个阶段。 } \\
\text { Penulis pada saat proses menerjemahkan brosur memiliki } \\
\text { tiga tahapan. }\end{array}$ \\
\hline 2. & $\begin{array}{l}\text { 所以结果汉语旅游 } \\
\text { 的视频对外国游客 } \\
\text { 的促进更好。(*) } \\
\text { Oleh karena itu hasil } \\
\text { video pariwisata } \\
\text { bahasa Mandarin } \\
\text { sangat baik bagi } \\
\text { kemajuan wisatawan } \\
\text { asing. }\end{array}$ & $\begin{array}{l}\text { 所以实习结果是有了汉语旅游的视频, 这个对外国游客的 } \\
\text { 促进更好。 } \\
\text { Oleh karena itu hasil praktik kerja adalah adanya video } \\
\text { pariwisata berbahasa Mandarin, hal ini lebih baik bagi } \\
\text { kemajuan wistawan asing. }\end{array}$ \\
\hline
\end{tabular}




\begin{tabular}{|c|c|c|}
\hline 3. & $\begin{array}{l}\text { 所以结果汉语旅游 } \\
\text { 的视频对外国游客 } \\
\text { 的促进更好。(*) } \\
\text { Oleh karena itu hasil } \\
\text { video pariwisata } \\
\text { bahasa Mandarin } \\
\text { sangat baik bagi } \\
\text { kemajuan wisatawan } \\
\text { asing. }\end{array}$ & $\begin{array}{l}\text { 所以实习结果是有了汉语旅游的视频, 这个对外国游客的 } \\
\text { 促进更好。 } \\
\text { Oleh karena itu hasil praktik kerja ini adalah adanya video } \\
\text { pariwisata berbahasa Mandarin, hal ini lebih baik bagi } \\
\text { kemajuan wistawan asing. }\end{array}$ \\
\hline 4. & $\begin{array}{l}\text { 翻译转单的赾程有 } \\
\text { 三个阶段。(*) } \\
\text { Proses } \\
\text { menerjemahkan } \\
\text { brosur memiliki tiga } \\
\text { tahapan. }\end{array}$ & $\begin{array}{l}\text { 作者在翻译转单的过程中有三个阶段。 } \\
\text { Penulis dalam proses penerjemahan memiliki tiga tahapan. }\end{array}$ \\
\hline
\end{tabular}

Table 1 shows that the error found in the first sentence was included in lack of subject 作 者 (zuòzhě), while that in the second sentence was included in lack of word 实习 (shíxí). The first and second sentences were not in line with the Mandarin grammatical orders. Thus, at the beginning of the sentence, the subject should be added to clarify the sentence meaning to avoid misunderstanding and following the Mandarin standard language to form an effective sentence. The third and fourth sentences had the errors included in the deletion of auxiliary in sentences. Mandarin auxiliaries are divided into two: 助词 such as 、得地地、地、呢、吧, etc., and 助动词 such as 能、会、想、之、应该、中, etc. The third sentence omitted the word 了, which should exist and explain that the activity was completed.

Meanwhile, the fourth sentence omitted the word "中", which should explain the completed activities. In Mandarin, there is a pair of words which must be used: "在 中". Thus, the omission of the word "中" in the sentence broke the Mandarin grammatical rules.

\section{Causes of Errors}

Based on the analysis results on the errors found in the tiyao written by the students of Mandarin 3-Year Diploma Study Program of Universitas Jenderal Soedirman and questionnaires, 
the researcher found several factors causing the errors made by the students in writing their Tiyao. First, the students combined and implemented the Mandarin grammatical rules based on their mother tongue and consequently produced different sentence structures. Second, the students were still lack of knowledge in mastering the Mandarin vocabulary. Thus, they had difficulties in arranging words to the right sentence orders. Third, the students are lack understanding of the Mandarin standard written forms. Thus, the sentences made by the students were still in the form of spoken language. Besides, the students were still lack of practice in writing good and proper sentences.

\section{Conclusions and Suggestions}

\section{Conclusions}

Based on the research results, it was concluded that the errors found in the tiyao written by the students of the Mandarin 3-Year Diploma Study Program were classified into syntactical, semantic, morphological, and discourse levels. At the syntactical level, the researcher found several types of errors, such as the absence of a subject resulting in an ineffective sentence. The researcher also found several errors at the semantic level, such as in word selection (diction). At the morphological level, especially related to Mandarin phrases and clauses, the researcher found errors in the absence of adverbs in phrases and the absence of auxiliaries. At the discourse level, the researcher found the errors in the incomplete sentences throughout the paragraphs and consequently changed the sentence meaning. In general, the most errors made by the students in writing their tiyao were at the syntactical level, especially in forming effective sentences consisting of $\mathrm{S}+\mathrm{V}+\mathrm{O}+$ Adverb.

\section{Suggestions}

Based on the research results, the researcher has some suggestions:

1) Complete procedures for writing good Mandarin sentences based on the Mandarin language written standard should be well explained.

2) Reading more Mandarin grammar books, newspapers, and magazines written in Mandarin standard language can improve the students' competence and motivation in learning the Mandarin language, especially in writing Tiyao

\section{References}

Ca'en, Liu. 2001. 词语用法详解. Beijing: 北京语言文化大学出版社.

Chomsky, Noam. 1965. Aspects of the Theory of Syntax. Cambridge, Massachusetts: MIT Press. 
Delu, Li. 2016. 汉语语法教学. Beijing: 北京语言大学出版社.

Jianqin, Wang. 2012. 第二语言习得研究. Beijing: 商务印书馆出版社.

Syafi'ie Iman, et al. 1981. Pendekatan Pembelajaran Bahasa Indonesia [Indonesian Language Learning Approach]. Jakarta: Pusat Penerbit UT.

Mansoer, Pateda. 1989. Analisis Kesalahan [Errors Analysis]. Flores. NTT: Nusa Indah.

Moeliono, Anton et al. 1988. Tata Bahasa Baku Bahasa Indonesia [Indonesian Language Formal Grammatical patterns]. Jakarta : Balai Pustaka.

Parera, Jos Daniel. 2009. Dasar-Dasar Analisis Sintaksis [Sintactical Analysis Principles]. Jakarta: Erlangga press.

Rusmadji, Oscar. 1993. Aspek-aspek Sintaksis [Sintactic Aspects]. Malang: IKIP Malang.

Shuxiang, Lü and Ding Shengshu. 2016. Xiandai Hanyu Cidian. China: Commercial Press.

Sugihastuti. 2000. Wanita di mata wanita (perspektif sajak-sajak Toety Heraty) [Women in the Perspective of Women (The Perspectives of Rhymes Written by Toety Heraty)]. Bandung: Nuansa Publisher.

Sukardi. 2003. Metodologi Penelitian Pendidikan [Educational Research Methodologies]. Jakarta: Bumi Aksara

Tarigan \& Guntur, Henry. 1986. Prinsip-prinsip Dasar Sintaksis [Sintactic Basic Principles]. Bandung: Angkasa.

Tarigan \& Guntur, Henry. 1988. Pengajaran Analisis Kesalahan Berbahasa [Linguistic Errors Analytical Learning]. Bandung: Angkasa Bandung.

Xiaochuan, Peng et al. 2013. 对外汉语教学语法释疑 201 例. Beijing: 商务书馆.

Xun, Liu. 2010. 对外汉语教育学弓/论. Beijing: 北京语言大学出版社.

\section{Dictionary:}

Shuxiang, Lu. (2016). 现代汉语八百司. Beijing: 商务印书馆. 